\title{
Persepsi Perilaku Seksual: Perilaku Seksual Pra-Nikah Mahasiswa di Kecamatan Jebres Kota Surakarta
}

\author{
ARIS MARTIANA \\ Jurusan Pendidikan Sosiologi \\ Fakultas Ilmu Sosial Universitas Negeri Yogyakarta \\ aris.martiana85@gmail.com
}

\begin{abstract}
Abstrak
Perilaku seksual pra-nikah saat ini sudah banyak terjadi, bahkan pelakunya adalah mahasiswa perguruan tinggi yang memiliki idealisme. Mahasiswa hidup ditengah masyarakat sosial dengan berbagai aktivitasnya yang tentunya tidak terlepas dari persepsi masyarakat. Penelitian ini mengambil lokasi di Kecamatan Jebres Kota Surakarta yang mempunyai latarbelakang sejarah dan budaya kuat. Penelitian ini bertujuan untuk mengetahui persepsi yang ada dalam masyarakat tentang perilaku seksual pra-nikah mahasiswa. Penelitian ini adalah penelitian deskriptif kualitatif. Sesuai dengan tujuan penelitian digunakan teknik cuplikan yaitu snowball sampling dan purposive sampling dengan teknik pengumpulan data menggunakan observasi, wawancara dan dokumentasi. Analisis data dengan menggunakan teknik analisa data model interaktif. Hasil penelitian ini menunjukan bahwa persepsi masyarakat dibedakan menjadi tiga yaitu (1). Melarang dengan keras proses pacaran dan perilaku seksual pra-nikah, (2). Membolehkan proses pacaran dengan batas-batas tertentu yaitu ditahap berpegangan tangan dan tahap berciuman, (3). Permissif terhadap proses pacaran dan perilaku seksual pra-nikah pada tahap hubungan seksual dikalangan mahasiswa.
\end{abstract}

Kata kunci : Persepsi, Perilaku Seksual Pra-nikah, dan Mahasiswa

\begin{abstract}
Pre-marital sexual behavior now widely happens, even the actor is a college student who has idealism. Students live in social life in the community with a variety of activities that must not be separated from public perception. This research took place in the District of Jebres Surakarta which has strong historical and cultural background. This research aims to determine the perceptions that exist in society about pre-marital sexual behavior of students. This is a qualitative descriptive research. In accordance with the purpose of research,purposive and snowball sampling techniques were applied. The data collection techniques include observations, interviews and documentation. Data analysis was performed using interactive models techniques. These results indicate that public perception can be divided into three, namely (1) prohibit the process and pre-marital sexual behavior, (2) allow the dating process with specific boundaries of holding hands and kissing stage, (3) Permit the process of dating and sexual behavior at the stage of pre-marital sexual relations among students.
\end{abstract}

Keywords : Perception, Pre -marital sexual behavior, and Students 


\section{PENDAHULUAN}

Masyarakat merupakan suatu kehidupan kolektif yang sangat dekat dengan seseorang dan menjadi tempat untuk bersosialisasi. Pembentukan budaya juga terjadi dalam masyarakat yang nantinya akan memberi pengaruh terhadap kepribadian seseorang. Adapun pengertian masyarakat menurut Koentjaraningrat (1985: 143) untuk menyebut kesatuan-kesatuan hidup manusia digunakan istilah masyarakat yang dalam bahasa inggris dipakai istilah society yang berasal dari kata latin socius yang berarti kawan. Istilah masyarakat berasal dari akar kata Arab syaraka yang berarti "ikut serta berpartisipasi". Individu berjumlah banyak menghuni sebuah komunitas yang sering disebut masyarakat, mereka berkawan dan tidak bisa hidup sendiri, kehidupan saling membantu guna tercipta kebersamaan akan mewarnainya. Karena itulah manusia juga dikenal dengan makhluk sosial.

Setiap masyarakat memiliki kehidupan sosial budaya yang berbeda, salah satu yang telah lahir dari masyarakat yakni persepsi. Persepsi antara individu satu dengan yang lainnya mengalami perbedaan begitu juga persepsi dalam sebuah komunitas. Persepsimerupakan suatu bagian dari kehidupan masyarakat sebagai komunitas kelompok. Dari sini dapat diketahui pengertian persepsi itu sendiri bahwa Mahmud (1990: 41) mengungkapkan "persepsi adalahmenafsirkan stimulus yang telah ada di dalam otak". Selain itu Atkinson dkk (1999: 201) juga menjelaskan tentang pengertian persepsi yaitu "proses dimana kita mengorganisasikan dan menafsirkan pola stimulus ini dalam lingkungan". Persepsi masyarakat terhadap sesuatu berbeda-beda seperti halnya persepsi tentang perilaku seksual pra-nikah dikalangan mahasiswa.

Bukan rahasia umum lagi bahwa banyak sekali fenomena perilaku seksual pra-nikah yang ada di masyarakat. Lebih khususnya yang terjadi pada mahasiswa. Perilaku tersebut bermula dari adanya ketertarikan antara lawan jenis dan mereka menjalin hubungan lebih dekat atau yang sering dikenal dengan istilah pacaran. Pacaran menjadi hal yang sudah biasa dilihat dan dilakukan oleh seseorang untuk saat ini. Bukan lagi menjadi hal yang tabu atau dilarang. Ada yang bertujuan sampai kejenjang pernikahan dan ada juga yang tidak sampai ke pernikahan. Akan tetapi dalam proses pacaran tersebut banyak yang melakukan perilaku seksual seperti layaknya pasangan yang sudah menikah. Seperti yang diungkapkan oleh PILAR PKBI Jawa Tengah tahun 2004 dalam aktivitas berpacaran telah dilakukan: $100 \%$ ngobrol; $93,3 \%$ pegang tangan; $84,6 \%$ cium pipi/kening; $60,9 \%$ cium bibir; $36,1 \%$ cium leher; $25 \%$ meraba/petting; 7,6\% intercourse (Asti, 2005: 57). Bahkan perilaku seksual seperti berpelukan dan berciuman itu juga dilakukan ditempat umum. Fenomena tersebut menjadi pusat perhatian bagi masyarakat dan sebuah masalah serius mengingat para pelaku adalah mahasiswa sebagai generasi penerus bangsa. Sosok remaja akhir menuju dewasa untuk memimpin bangsa dan membawa bangsa mewujudkan cita-cita dasar negara dikemudian hari. Persepsi dalam masyarakat muncul di kehidupan sosial budaya yang bervariasi.

Untuk mengetahui persepsi yang hidup di masyarakat tentang perilaku seksual pra-nikah dikalangan mahasiswa dilakukan penelitian terhadap masyarakat kecamatan Jebres Kota Surakarta. Dengan diketahuinya ada variasi persepsi diharapkan akan menjadi kontrol sosial dalam masyarakat sehingga perilaku tersebut dapat diminimalisir. Persepsi yang ada akan memberikan efek pada budaya di lingkungannya sebagai tempat sosialisasi anak dalam pembentukan kepribadian.

\section{METODE}

Penelitian ini menggunakan metodekualitatif deskriptif karena difokuskan padapersepsi masyarakat, dengan menggunakan metode tersebut akan mendapatkan berbagai informasi secara deskriptif. Tempatpenelitianyaitu di kecamatan Jebres,Kota Surakarta, Jawa Tengah, dengan teknik cuplikan yang digunakan yaitu snowball sampling dan purposive sampling karena ada penentuan informan sebagaipemegang kunci kemudian pemilihan informan selanjutnyamenggunak- 
an teknik snowball sampling karena banyak yang tidak mengetahui informan sebelumnya. Teknik pengumpulan data menggunakan wawancara, observasi dan analisis dokumen. Analisis data dalam penelitian ini menggunakan analisis interaktif menurut Matthew B. Miles dan A. Michael Huberman(1992) yaitu meliputi reduksi data, sajian data, dan penarikan simpulan.

\section{HASIL DAN PEMBAHASAN}

Persepsi merupakan aktivitas dalam mengidentifikasikan dan melihat suatu fenomena melalui pancaindera. Kemudian akan terbentuk sebuah persepsi terhadap suatu fenomena. Pada penelitian ini dipilih informan masyarakat yang tinggal di wilayah Jebres, Kota Surakarta. Ada beberapa pertimbangan dalam memilih lokasi tersebut antara lain Kota Surakarta memiliki beberapa lembaga pendidikan tinggi negeri maupun swasta. Lembaga-lembaga pendidikan tinggi yang ada di daerah Jebres antara lain Universitas Sebelas Maret Kentingan Surakarta, Institut Seni Indonesia Kota Surakarta, dan Sekolah Tinggi Ilmu Kesehatan Aisyiah Surakarta. Dengan adanya beberapa lembaga pendidikan tinggi tersebut maka wilayah Jebres menjadi padat dengan adanya pendatang mahasiswa yang bukan berasal dari wilayah itu. Untuk itu, penduduk Jebres membangun rumah atau kamar untuk disewakan dengan sistem kontrak maupun kos. Disamping itu secara waktu, tenaga dan biaya lebih efisien bagi peneliti serta di wilayah tersebut terdapat fasilitas umum untuk mengakses informasi antara lain warung internet, kios rental VCD, dan kios rental buku bacaan. Dengan demikian wilayah Kecamatan Jebres menjadi tempat penelitian adalah suatu pertimbangan yang logis. Selain itu Kota Surakarta dipilih memang karena kota tersebutdikenal dengan budaya Jawa yang masih cukup kental sehingga latar belakang budaya masyarakat akan mempengaruhi persepsi mereka.

Masyarakat memiliki kekuatan luar biasa dalam hal persepsi yang akan mampu mengubah kebudayaan lingkungannya. Masyarakat merupakan kesatuan hidup sekelompok manusia dan tiap individu di lingkungan ma- syarakat di daerah lain. Begitu pula karakter individu secara pribadi. Mereka mempunyai pandangan yang berbeda-beda terhadap permasalahan yang diteliti. Persepsi yang terjadi dalam masyarakat disebabkan karena adanya stimulus dari eksternal dan subyektifitas individu akan mempengaruhi persepsi tersebut menjadi berbeda-beda. Hal yang mempengaruhi persepsi ada berbagai faktor seperti yang diungkapkan oleh Mahmud (1990: 52) antara lain: a. faktor mental; b. faktor suasana emosi; c. Keinginan yang kuat atau sikap. Faktor-faktor tersebut memberikan pengaruh terhadap perbedaan persepsi yang dimiliki oleh masyarakat. Ketiga faktor tersebut dapat digolongkan sebagai faktor subyektifitas individu. Apa yang terjadi dalam dirinya memberikan efek sebuah persepsi yang tentu didukung oleh faktor eksternal yakni secara umum adalah lingkungan yang dia tempati. Berdasarkan data di lapangan telah ditemukan pengklasifikasian persepsi masyarakat. Dalam masyarakat terdapat beberapa kubu yang pro dan kontra terhadap perilaku seksual pra-nikah bahkan ada yang bersikap biasa-biasa saja. Berikut pemaparan persepsi masyarakat dari hasil penelitian di lapangan:

\section{Masyarakat tidak setuju perilaku sek- sual pra-nikah}

Ketidaksetujuan mereka menyangkutnilai dan norma yang terjadi di lingkungan kehidupan masyarakat sehingga terbentuk persepsi yang melarang keras terhadapfenomena pacaran saat ini apalagi terhadap perilaku seksual pra-nikah. Masyarakat tersebut berpersepsi dari segi aturan agama yang mereka yakini, yang memiliki aturan pelarangan dalam perilaku tersebut. Seperti yang diungkapkanoleh KR pria yang secara penampilan sangat agamis danmerupakan ketua RT di lingkungan setempat mengatakan bahwa :

"Pacaran kalau saya mengukurnya dari agama bila melihat pacaran saat ini saya menolak dan saya akan mencegah sekuat saya. Menurut saya pacaran banyak melanggar saya tidak setuju 
mestinya nikah dulu baru pacaran." (W/ $K R / 12 / 4 / 10$ )

Hal senada juga diungkapkan oleh AS yang selalu berpenampilan rapi mengatakan bahwa:

"Menurut saya pacaran kebetulan saya tahu agama ya itu gak bagus, umumnya orang perbuatan itu wajartapi berhubung saya ngerti agama itu gak setuju dengan pacaran." (W/AS/23/11/09)

Untuk SM yang berprofesi sebagai guru SD mengatakan,

"Kalau pacaran gak boleh, manfaatnya kurang banyak. Pokoknya kebanyakan tidak bermanfaat. Untuk perilaku seksual pra-nikahnya jangan sampai terjadi mendingan cepet-cepet nikah. Menjurusjurus malahan bencana atau musibah. Saya tidak setuju." (W/SM/31/4/10)

Sesuai pernyataan masyarakat tersebut mereka memberikan suatu respon terhadap fenomena berpacaran sekarang yang dilakukan oleh remaja dengan menggunakan pengalaman-pengalaman yang mereka miliki dan dimensi agama yang mendominasi setiap perilaku dan tindakan mereka bertigadalammemberikan persepsi terhadap lingkungan sekitar. apat dikatakan pendapat dan sikap tersebut sangat kontra dengan fenomena yang terjadi. Meskipun demikian merekatidak bertindak secara radikal dalam merealisasikan ketidaksetujuan mereka. Secara kebetulan disekitar tempat mereka tinggal terdapat beberapa rumah kosdanrumah kontrakanada yang dihuni oleh mahasiswa dan keluarga. Untuk mahasiswa masih sangat ketat peraturannya. Untuk itu, dapat dipantau dengan baik. Lokasi rumah kos berdekatan dengankediaman ketiga tokoh masyarakat tersebut. KR yang bekerja sebagai karyawan mengutarakan :

"Di RT, kos ada tiga, didepan itu untuk cowok, diseberang jalan juga ada kos cowok, tapi jarang menyediakan kos, untuk perempuan sangat sedikit hanya satu. Kadang terlihat ada cewek dikos tersebut kalau siang dan sore hari. Di luar RT 04 pemiliknya terpisah disini kebanyakan rumah penduduk" (W/ $K R / 12 / 4 / 10$ )

Sedangkan AS yang berwiraswasta sebagai pedagang juga mengutarakan :

"Sekitar 50 meter ada kos putra masih satu RW tapi RTnya lain. Pemilik kos rumahe gak ada, gak pernah kesini.kalau di RW lain ada kos yang campur antara putra dan putri. " (W/AS/23/11/10)

SM juga mengatakan bahwa :

"Kalau dilingkungan sini ada yang untuk keluarga juga kos mahasiswa. Sekitar ada sepuluh rumah yang dikoskan. Tetapi disini lingkungan sekitar sangat ketat dan bersifat agamis banyak santri dan ustadz juga." (W/SM/31/4/10)

Rumah kos di sekitar informan masyarakat tersebut bersifat terbuka dalam arti lawan jenis diperbolehkan masuk. Dimana untuk tiap minggunya sepi karena mahasiswa kos banyak pulang kedaerah asalnya. Menurut pendapat tokoh tersebut rumah kos yang ada di lingkungan baik-baik saja maksudnya belum ada permasalahan yang menyimpang dari peraturan yang ada di lingkungan sehingga mereka hanya sebatas mengawasi. Untuk tamu lawan jenis merekamasih memberikan kelonggaran dalam arti masih diperbolehkan tetapi sesuai dengan aturan. Seperti yang diungkapkan oleh KR bahwa:

"Tamu lawan jenis di kos ya ada, tapi saya jarang lihat karena bekerja. Kalo malam ya maksimal jam sepuluh, belum pernah ada kasus. Dilingkungan sini juga tidak ada ronda, keamanan dijalanin sendiri." (W/KR/12/4/10)

Informan KR, AS, dan SM berharap lingkungannya tidak mengarah pada lingkungan yang memperbolehkan ada rumah kos yang bebas. Walaupun tetap mengijinkan ada tamu lawan jenis datang di rumah kos. Seperti yang diungkapkan oleh AS yang merupakan penduduk asli daerah tersebut:

"Pandangan saya mengenai kos harusnya sesuai dengan keyakinan, putri sendiri, putra sendiri, kalo untuk rumah tangga lain lagi ada putra dan putri. Jadi gak bebas campur putra dan putri." (W/ 


\section{$A S / 23 / 11 / 09)$}

Di samping pengamatan tentang keadaan rumah kos di sekitar mereka dan mengenai kos bebas, tokoh masyarakat tersebut juga mempunyai persepsi terhadap perilaku seksual pra-nikah atau lebih dikenal dengan pacaran dengan melakukan aktivitas seksual, mereka dengan keras melarangnya. Berikut ini penuturan KR :

"Banyakyang pacaran karena kurangnya pemahaman agama dan pengaruhpengaruh teknologi dan kemajuan. Anakanak tetap aku pesen jangan sampai melanggar agama, dilarang pacaran. Untuk jaman sekarang pergaulan yang bebas, kembali lagi pada diri yang ukurannya iman, bila yang lemah maka melakukan seks pra nikah, padahal di agamaku hukumnya keras." (W/ KR/12/4/10)

Pernyataan senada juga disampaikan oleh AS bahwa :

"Karena saya kan tahu agama, saya larang. Bukan keras tapi yang benar itu benar, pacaran dengan perilaku seks barangkali di umum biasanya setuju sedang saya itu perbuatan melanggar, hukumnya aja di dera dalam agama." (W/AS/23/11/09)

Begitu juga penuturannya dari SM yang berpendidikan D2 PGSD :

"Saya tidak setuju. Tidak bagus, banyak hal-hal yang tidak baik dalam pergaulan bebas. Anak mahasiswa nanti tujuannya tidak jadi kuliah malahan bergaul terus." (W/SM/31/4/10).

Persepsi sebenarnya merupakan kumpulan-kumpulan pengalaman-pengalaman yang ada disekitar sehingga di sini lingkungan sangat berperan. Seperti ungkapan Lewin (1951) dan Heider (1958) yang dikutip oleh Yusmar Yusuf (1991: 107) bahwa faktor sosial dan lingkungan merupakan faktor terpenting dalam pembentukan persepsi. Tentunya bila melihat kedua faktor tersebut maka muncullah kebudayaan sebagai sesuatu yang mempengaruhi persepsi masyarakat.

Daripemaparan tersebut untuk memben- tuksuatu persepsi dimana persepsi sendiri merupakan suatu pemaknaan hasil inderawi khususnya dalam hal pengamatan maka sangat berkaitan dengan lingkungan dan kebudayaan yang mampu menjadi stimuli bagi individu.

\section{Masyarakat membolehkan berpa- caran dengan batas-batas tertentu}

Ada masyarakat menyatakan bahwa pacaran diperbolehkan tetapi jangan sampai melewati batas nilai dan norma yang berlaku di komunitas tersebut. Merekamemberi ijin adanya fenomena pacaran akan tetapi tidak sampai melakukan intercourse. Sehingga pacaran tersebut hanya sebatas pada tingkatantingkatan tertentu antara lain bergandengan tangan dan berciuman. Menurut DI perempuan yang belum berkeluarga mengatakan bahwa:

"Pacaran adalah menjalin hubungan atas dasar suka sama suka." (W/DI/10/5/10)

Begitu juga yang dikatakan oleh $\mathrm{AL}$ yang bekerja sebagai penjaga konter handphone dibelakang kampus UNS mempunyai pendapat tentang pacaran mengatakan bahwa:

"Pacaran dulu gak penting tapi sekarang pacaran ki penting. Aku juga pacaran kok tapi jarak jauh sih, pulange empat bulan sekali." (W/AL/11/5/10)

Menurut mereka di lingkungan sekitarnya memang sudah terlihat banyak perilaku pacaran dari anak kecil sampai yang sudah berusia tua. Bahkan sekarang menjamur rumah kos yang bebas dengan membolehkan lawan jenis masuk ke dalam rumah kos bahkan menginap. Seperti yang diungkapkan oleh DI:

"Ada rumah kos bebas dan campur sekitar tiga rumah. Malah ada yen malam dinas loh. Ya itu dians keluar malam, jadi orang gak bener alias menjual diri." (W/ DI/10/5/10).

Hal tersebut juga diutarakan oleh AL yang masih berusia 18 tahun bahwa:

"Daerahku ada dua rumah kos mbak, 
isinya cowok-cowok kebanyakan yang sekolahe perawat-perawat. Memang kalau yang bebas kebanyakan cowok. Kalau depan konterku ini kos cewek sering sih tamu cowok datang tapi masih diteras gak masuk ke dalam. Walau gak ada pemilik kosnya Cuma ada yang ngurusin kos mas-mas yang jualan hik didepan ituloh mbak." (W/AL/11/5/10)

DI yang bekerja sebagai pengajar juga menambahkan tentang kos bebas:

"Sebenarnya perlu ada pengawasan dari ibu kos ada pembatasan penghuni koslah." (W/DI/10/5/10)

Begitu juga AL mengatakan bahwa:

"Kalau rumah kos bebas gak baik kampung jadi tercemar kasihan yang punya. Kan juga gak disini. Walau benere aku cuek urusan-urusanmu dewe." (W/ DI/10/5/10)

Kos bebas di sekitar mereka tinggal mulai menjamur. Bahkan lingkungan seolah-olah acuh tak acuh terhadap fenomena tersebut. Seperti yang diungkapkan oleh DI:

"Wah ngerti-ngerti meteng, gak tahu dikruduk. Nek ora nikah pirang sasi terus nglairke." (W/DI/10/5/10)

"Wah tahu-tahu hamil, tidak pernah dikepung. Kalau tidak menikah beberapa bulan lalu melahirkan."

Mereka sebenarnya membolehkan berpacaran tetapi masih dalam batas kewajaran yang tidak menyangkut tentang seks. Dalam hal ini mereka juga telah memiliki pacar. Berikut penuturan DI:

"Batas perilaku seks pada pacaran sejauh berpegangan tangan sebagai wujud perlindungan seseorang laki-laki terhadap perempuan. Kalau seks bebas tidak setuju karena melanggar normanorma atau aturan yang berlaku baik agama maupun sosial. Di sini kan seks bebas berarti perilaku menyimpang yang ditandai dengan melakukan hubungan intim dengan pasangan tanpa ikatan yang sah atau perkawinan." (W/ DI/10/5/10)
Begitu juga dikatakan AL yang ingin segera menikah bahwa:

"Kalau pacaran ada perilaku seksual pranikah itu pacaran kaya gitu gak serius. Aka gak setuju karena sebagai cewek rugi. Pacaran biasa aja atau sewajarnya ya palingan cium pipi, makane aku juga pingin cepet nikah moga ini yang terakhir kali. Tapi aku cueklah urusan-urusanmu dewe." (W/AL/11/5/10)

Berdasarkan persepsi masyarakat diatas tentang perilaku seksual pra-nikah mereka tidak menyetujuinya. Hal tersebut bertolak dengan adanya nilai dan norma yang diyakini salah satunya adalah agama. Persepsi tersebut juga terbentuk karena keadaan lingkungan yang masih kondusif dan dalam hal-hal perilaku menyimpang hampir tidak ada. Sedangkan dalam kegiatan keagamaan ada bebrapa informan masyarakat aktif dan warga sekitarnya yang lain juga berpartisipasi. Untuk KR selain dia sebagai ketua RT setempat, dia juga merupakan tokoh agama di lingkungan sekitarnya dan SM sebagai guru juga AS yang membentuk keluarga yang sangat agamis berpersepsi dari dimensi keagamaan yang mengajarkan bahwa perilaku seksual pra-nikah sangat keras hukumnya. Sedangkan informan AL dan DI membolehkan berpacaran tetapi untuk perilaku seksual pra-nikah yang lebih dari berciuman dan sudahmenjurus pada hubungan suami isteri mereka menolak. Meskipun memang ada yang permissif terhadap perilaku tersebut seperti DJ dan SJ mereka mengembalikan semua pada diri pelaku masing-masing terhadap akibatnya.Tumbuhnya persepsi tersebut di masyarakat membuat informan harus memilih peran dan berupaya membangunnya. Padahal informan sebagai mahasiswa pelaku seksual pra-nikah yang sudah mencapai tingkatan seksual sampai pada hubungan seksual dan yang paling rendah adalah bergandengan tangan dan berciuman bibir.

\section{Masyarakat membolehkan perilaku seksual pra-nikah}

Berdasarkan informan dilapanganmaka ditemukan persepsi masyarakat membole- 
hkan bahkan cenderung cuek pada perilaku berpacaran mahasiswa yang melibatkan perilaku-perilaku seksual. Adanya fenomena berpacaran bebas dan rumah kos bersifat bebas untuk lawan jenis menjadi hal yang biasa dilihat dan ditemui dikehidupan sehari-hari. Mereka tidak mempermasalahkan perilaku tersebut. Berikut akan lebih dijelaskan mengenai persepsi masyarakat tersebut sesuai penuturan DJ yang berusia 24 tahun:

"Kos disekitar sangat banyak baik cowok maupun cewek. Bahkan ada yang kos bebas cowok. Kalo yang cewek disekitar sini masih ada terasnya. Jadi masih mending. Rumah kos bebas biasa saja yang menarik apa? Kebebasan menuntut apa yang dia lakukan. Biasanya cewek dibatasin cowok bebas." (W/DJ/4/05/10)

SJ juga mengatakan bahwa:

"Saya punya kos mulai bukaan UNS. Kosnya buat laki-laki,kalau cewek disamping tempate kurang memnuhi syarat harus mengawasi padahal saya sering merantau, di daerah sini banyak rumah kos-kosan, rame banget mbak." (W/SJ/27/04/10)

Dari pernyataan mereka sebagai warga masyarakat biasa bukan sebagai pengurus RT, RW, ataupun kelurahan setempat juga bukan pula tokoh masyarakat yang menjelaskan tentang mahasiswa kos di daerah Jebres sekitar kampus UNS. Banyak warga sekitar yang membuka rumah kos seperti SJ. Dia juga menerapkan kos bebas seperti yang dikatakannya:

"Masuk kesini bebas gak ada jam malam, bebas nonstop mau tak kasih pintu tapi anak sekolah nek kegiatan siang sampai malam daripada ketok-ketok, 24 jam terbuka. Bawa cewek ya silahkan... pokoknya tanggungjawab aja. Kalau sampai menghamili ya harus dinikahi. Kalau tidak nanti tak cari sampai ke alamat rumahnya." (W/SJ/27/04/10)

Sedangkan untuk alasan yang dia ungkapkan mengenai kebebasan diberikan kepada anak-anak kosnya adalah sebagai berikut:

"Alasannya ya mbak karena saya pernah muda, sejak pertama udah bebas, anak kos itu gak ada hiburan jadi ya dimaklumilah. Harga kamar juga terjangkau saya mengingat belum tentu anak-anak mahasiswa itu kaya, bikin rata-rata aja." (W/SJ?27/04/10)

Berkaitan dengan persepsi mereka terhadap fenomena berpacaran saat ini, baik SJ maupun DJ mempunyai persepsi terhadap konsep pacaran. Untuk SJ mengungkapkan:

"Pacaran bisa mendekatkan dua belah pihak untuk mengikat dalam sementara waktu,pacaran tergantung individu masing-masing. Mengikuti jaman sekarang kadang-kadang ilmune lebih tinggi dari jaman dulu danbiasanya anak-anak pacaran ikuti jaman." (W/ SJ/27/04/10)

Sedangkan DJ mengatakan bahwa:

"Pacaran itu sebatas menjalin hubungan mengenal satu sama lain, karakter, watak, visi, dan misi satu dengan lainnya jika tidak ada yang sinkron maka tidak ada kecocokan. Untuk sekarang banyak yang nabung dulu baru merit. Kalau di kos mesti pada tutupkamar dan ya udah tahu yang dilakuin apa aja. Paling ya gitu-gitu." (W/DJ/4/05/10)

Mereka tidakmelarang adanya perilaku berpacaran bahkan mereka membolehkan adanya proses pacaran. Mengenai kos bebas yang ada di lingkungannya, mereka mempunyai pandangan dan persepsi yang secara umum tidak memperdulikan bahkan membolehkan. Hal itu senada dengan penjelasan DJ sebagai berikut:

"Kalau di sekitar sini kos cowok yang bebas kalau cewek tidak. Pernah sih ada yang bebas ceweknya terus dari RT dikasih surat edaran kalau tamu cowok maksimal jam 9.30 malam bertamu. Biasanya gaya mereka berpacaran dapat dari internet, ke warnet untuk searching. Mahasiswa aku prediksi 60-70\% pernah nonton film BF." (W/DJ/4/05/10)

Dari pernyataan mereka mengenai kos bebas adalah membiarkan bahkan cenderung membolehkan. Begitu juga persepsi mer- 
eka terhadap perilakus eksual pra-nikah juga cenderung membolehkan, membiarkan dan bersikap cuek. Berikut penjelasan SJ tentang pacaran dengan melakukan aktivitas seksual yang memiliki pendidikan SMP:

"Saya lihat anak-anak setiap hari bawa cewek, anak-anak remaja punya pacar pasti jalurnya kesitu entah ciuman, pelukan, ndak mungkin, ndak dijamin laki-laki perempuan Cuma ngobrol pasti kesitu jarang yang kaya gitu seribu satu. Baiknya cewek satu aja. Sekarang udah biasa, orangtua sekarang gak bisa mencegah anak muda, dulu juga udah banyak tapi belum seberani sekarang karena pengaruh-pengaruh televisi belum ada." (W/SJ/27/04/10)

DJ yang berprofesi sebagai pengajar juga mengatakan:

"Seks pra-nikah biasa aja, lah kehidupan agamis yang religius kental juga udah ada yang biasa melakukan yang dapat dosa kan mereka. Aku diam saja. Dalam menjalin hubungan harus ada pemikiran sebab akibat gitu deh." (W/DJ/4/05/10)

Dari penelitian yang dilakukan terdapat tiga persepsi yang diutarakan oleh masyara- kat di Kecamatan Jebres Kota Surakarta. KetigaPersepsitersebut sebenarnya merupakan kumpulan-kumpulan pengalaman-pengalaman yang ada disekitar sehingga di sini lingkungan sangat berperan. Seperti ungkapan Lewin (1951) dan Heider (1958) yang dikutip oleh Yusmar Yusuf (1991: 107) bahwa faktor sosial dan lingkungan merupakan faktor terpenting dalam pembentukan persepsi. Tentunya bila melihat kedua faktor tersebut maka muncullah kebudayaan sebagai sesuatu yang mempengaruhi persepsi masyarakat. Untuk membentuk suatu persepsi yang merupakansuatu pemaknaan hasil inderawi khususnya dalam hal pengamatan maka sangat berkaitan dengan lingkungan dan kebudayaan yang mampu menjadi stimuli bagi individu. Seperti yang diungkapkan oleh Davidoff (1981), Rogers (1965) (lewat Walgito, 2004) bahwa dalam persepsi karena perasaan, kemampuan berpikir, pengalaman-pengalaman individu tidak sama, maka dalam mempersepsi sesuatu stimulus, hasil persepsi mungkin akan berbeda antara individu satu dengan individu lain. Persepsi itu bersifat individual.

Berikut ini akan digambarkan bagan persepsi menurut Yusuf (1991: 109):

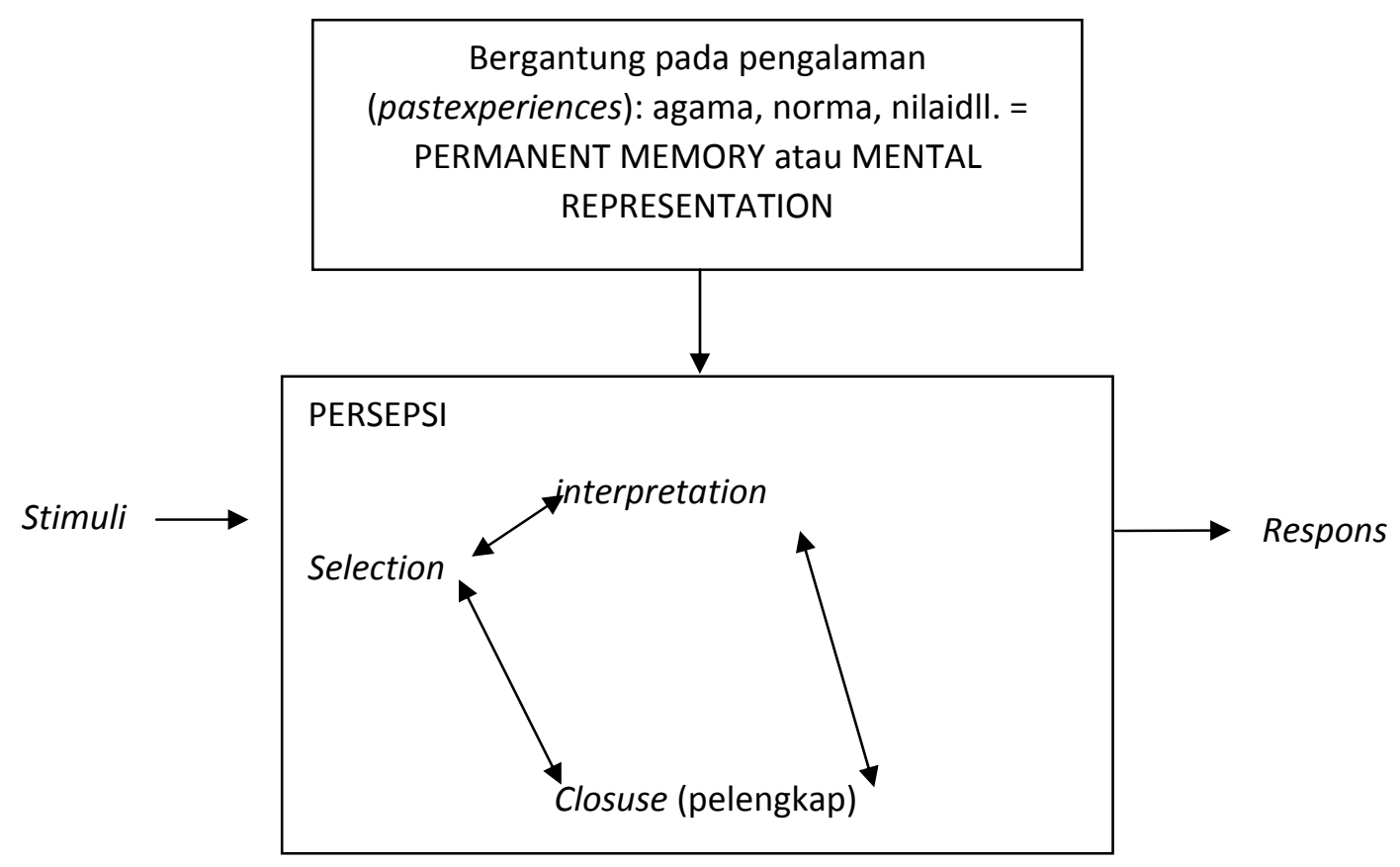


Pembentukan persepsi terhadap sesuatusehingga menimbulkan tanggapan maka harus ada rangsangan yang mampu menarik panca indera manusia kemudian mengalami proses pemilihan dalam menafsirkan dan melengkapi secara berkesinambungan yang tentunya hasil dari semua itu berupa persepsi yang dipengaruhi oleh pengalaman diri individu baik lingkungan agama, budaya ataupun lingkungan sosial. Di dalam kehidupan sosial ada sebuah pemahaman yang memang memberi makna pada persepsi masyarakat. Pemahaman seseorang akan berbeda-beda sehingga persepsinya juga berbeda.Pemahaman digunakan untuk mendapatkan sesuatu informasi sosial budaya di lingkungan masyarakat yang tidak hanya sekedar mengerti akan tetapi mampu memaknai sesuatu yang tentunya akan terbentuk pola persepsi. Bagi Weber verstehen adalah prosedur studi yang rasional, tidak hanya melibatkan intuisi, berdasarkan simpati dan bukan sekedar merasakan fenomena sosial. (Ritzer\&Goodman, 2009: 127). Pemahaman yang dilakukan tidak serta merta hanya melihat sekilas akan tetapi sudah melalui tahap pendalaman makna sehingga mampu melihat banyak penyebab seorang individu bertindak. Pemahaman verstehen ini sangat dibutuhkan dalam persepsi yang diberikan oleh masyarakat.

Untuk itu persepsi adalah ciptaan masyarakat yang telah terbangun. Meskipun demikian tentu pemikiran seseorang tetap tidak hanya didominasi oleh keadaan masyarakat, sebagaimana di kecamatan Jebres Kota Surakarta yang memiliki budaya Jawa dan terkenal dengan agamanya yang kuat masih memiliki persepsi masyarakat yang berbeda, tidak ada penyeragaman persepsi sehingga pada dasarnya persepsi masyarakat dipengaruhi akan banyak hal. Persepsi sosial selalu berubah-ubah seperti yang ditulis oleh Sarwono (2010: 103) bahwa ada hal-hal yang dapat menyebabkan perbedaan persepsi antarindividu dan antarkelompok antara lain: perhatian dalam fokus individu, set adalah kesiapan mental seseorang untuk menghadapi sesuatu rangsangan yang akan timbul dengan cara tertentu, kebutuhan yang berbeda juga akan mempengaruhi persepsi seseorang, sistem nilai yang berlaku dalam masyarakat, tipe kepribadian seseorang dan gangguan kejiwaan.

\section{SIMPULAN}

Berdasarkan hasil penelitian dan pembahasan yang telah diuraikan di atas maka dapat ditarik kesimpulan bahwa dalam persepsi masyarakat tentang perilaku seksual pra-nikah mahasiswa terbagi menjadi tiga persepsi yaitu :

1. Masyarakat memiliki persepsi melarang dengan keras proses pacaran danperilaku seksual pra-nikah yang dilakukan oleh mahasiswa dikarenakan melanggar nilai dan norma agama serta budaya lingkungan setempat.

2. Masyarakat memiliki persepsi membolehkan proses pacaran dengan batas-batas tertentu yaitu ditahap berpegangan tangan dan tahap berciuman akan tetapi melarang mahasiswa sampai melakukan hubungan seksual bahkan seks bebas dengan pertimbangan bahwa untuk kejenjang yang lebih serius/menikah dibutuhkan kedekatan untuk saling mengenal pasangan masing-masing.

3. Masyarakat memiliki persepsi membolehkan dan cenderung membiarkan mahasiswa berpacaran bahkan melakukan perilaku seksual pra-nikah hingga tahap hubungan seksual seperti suami istri. Mereka cuek akan perilaku yang dilakukan mahasiswa karena menurut mereka sudah kepentingan pribadi masingmasing juga mahasiswa adalah seorang yang sudah dewasa sehingga paham akan tanggungjawab diri pribadi..

\section{UCAPAN TERIMAKASIH}

Terimakasih disampaikan kepada semua pihak yang terlibat dalam penelitian ini sehingga terlaksana dengan baik dan tim redaksi Jurnal Socia Fakultas Ilmu Sosial 
Universitas Negeri Yogyakarta yang telah mempublikasikan penelitian ini.

\section{DAFTAR PUSTAKA}

Asti, BM. 2005. Jangan Pacarin Gue. Surakarta: Smart Media.

Atkinson, R.L., Atkinson, R.C., Hilgard, E.L. 1999. Pengantar Psikologi. Jakarta: Erlangga.

Koentjaraningrat. 1985. Pengantar IImu Antropologi. Jakarta: Rajawali Press.
Mahmud, M.D.1990. Psikologi Suatu Pengantar. Yogyakarta: BPFE.

Miles, M.B.\& Huberman, A.M. 1992. Analisis Data Kualitatif. Jakarta:UI Press.

Ritzer, G\& Goodman, J. D. 2009. Teori Sosiologi. Yogyakarta : Kreasi Wacana.

Sarwono, S. W. 2010. Pengantar Psikologi Umum. Jakarta: Rajawali Press.

Walgito, B. 2004. Pengantar Psikologi Umum. Yogyakarta : Andi Offset.

Yusuf, W. 1991. Psikologi Antarbudaya. Bandung: Rosdakarya. 